\title{
HUBUNGAN LINGKUNGAN FISIK RUMAH DENGAN KEJADIAN ISPA PADA BAYI
}

\author{
Vedjia Medhyna \\ STIKes Fort De Kock Stikes Fort De Kock Kota Bukittinggi, Sumatera Barat \\ vedjiamedhyna@gmail.com
}

\begin{abstract}
Salah satu penyebab kematian pada bayi di Indonesia adalah infeksi saluran pernapasan akut. Kejadian ISPA pada bayi dipengaruhi oleh beberapa faktor. Adapun tujuan penelitian ini untuk mengetahui hubungan lingkungan fisik rumah dengan kejadian ISPA di wilayah kerja Puskesmas Kabupaten Pasaman.Penelitian ini menggunakan disain prospektif, pengumpulan data dengan observasi lingkungan fisik rumah terhadap 175 bayi meliputi keadaan ventilasi rumah, jenis lantai, ventilasi dapur, kepadatan hunian, bahan bakar masak dan kejadian ISPA. Hasil analisis bivariat diketahui penyebab kejadian ISPA adalah ventilasi rumah $(p=0,004)$, jenis lantai $(p=0,035)$, kepadatan hunian $(p=0,039)$, dan ventilasi dapur $(p=0,038)$. Analisis multivariat didadapkan ventilasi rumah merupakan faktor paling dominan $(O R=3,192)$. Disimpulkan bahwa keadaan ventilasi rumah sangat mempengaruhi kejadian ISPA, disarankan kepada tenaga kesehatan lebih gencar memberikan penyuluhan pentingnya memperhatikan kondisi lingkungan rumah agar terhindar dari kejadian ISPA
\end{abstract}

Keywords: ventilasi rumah, jenis lantai, ventilasi dapur, kepadatan hunian, bahan bakar masa, ISPA

\begin{abstract}
Acute Respiratory Infection it still is one of cause of death in infants in Indonesia. Acute Respiratory Infection in the infant influence many factor. The purpose of this study is to define the correlation of environment with ARI at the Health Care in Pasaman Region.This study used prospektive design, the collection of data usingobservational against 175 infants as a sample to find out the house ventilation, the floor type, kitchen ventilation, residential density, fuel used to cook and the incidence of ARI. The result of bivariat analysis shows that the factor predisposing occurence of ARI was house ventilation ( $p$ $=0,004)$, floors type $(p=0,035)$, residential density $(p=0,039)$, and kitchen ventilation $(p=0,038)$. Multivariate analysis showsthat the house ventilation is the most dominant factor $(O R=3,192)$. The conclusion of this study was house ventilation influence of ARI, it is recommended to all health care provider to be more active providing counseling and education to community.
\end{abstract}

Keywords: the house ventilation, the floor type, kitchen ventilation, residential density, fuel used to cook, Acute Respiratory Infection

\section{PENDAHULUAN}

Di Indonesia, ISPA masih merupakan salah satu penyebab kematian pada bayi sebesar 12,7\%. Di Indonesia ISPA merupakan salah satu penyebab utama kunjungan pasien ke sarana kesehatan, 40$70 \%$ anak berobat ke Rumah Sakit adalah penderita ISPA.
Berdasarkan teori beberapa faktor yang mempengaruhi ISPA antara lain ventilasi, jenis lantai, ventilasi dapur, kepadatan hunian serta bahan bakar masak.

Berdasarkan latar belakang diatas, maka peneliti tertarik untuk melakukan penelitian tentang hubungan lingkungan fisik rumah dengan kejadian ISPA pada bayi. 


\section{METODE PENELITIAN}

Disain pada penelitian ini adalah prospektif dengan sampel penelitian 175 bayi di Wilayah kerja Puskesmas Kabupaten Pasaman. Pengumpulan data dengan melakukan observasi. Penelitian ini dilakukan mulai bulan April 2015 hingga Juni 2016.

\section{HASIL DAN PEMBAHASAN}

Tabel 1.Analisis Faktor Kejadian ISPA

\begin{tabular}{|c|c|c|c|c|c|c|}
\hline \multirow[t]{3}{*}{ Variabel } & \multicolumn{4}{|c|}{ Kejadia ISPA } & \multirow[t]{3}{*}{$\mathbf{n}$} & \multirow[t]{3}{*}{ P Value } \\
\hline & \multicolumn{2}{|c|}{ Ada } & \multicolumn{2}{|c|}{ Tidak ada } & & \\
\hline & f & $\%$ & f & $\%$ & & \\
\hline \multicolumn{7}{|l|}{ Ventilasi } \\
\hline TMS & 32 & 80,0 & 8 & 20,0 & 40 & 0,004 \\
\hline MS & 71 & 52,6 & 64 & 47,4 & 135 & \\
\hline Jumlah & 103 & 58,9 & 72 & 41,1 & 175 & \\
\hline \multicolumn{7}{|l|}{ Jenis Lantai : } \\
\hline TMS & 18 & 81,8 & 4 & 18,2 & 22 & 0,035 \\
\hline MS & 85 & 55,6 & 68 & 44,4 & 153 & \\
\hline Jumlah & 103 & 58,9 & 72 & 41,1 & 175 & \\
\hline \multicolumn{7}{|l|}{ Kepadatan } \\
\hline Padat & 36 & 72,0 & 14 & 28,0 & 50 & 0,039 \\
\hline Tdk padat & 67 & 53,6 & 58 & 46,6 & 125 & \\
\hline Jumlah & 103 & 58,9 & 72 & 41,1 & 175 & \\
\hline \multicolumn{7}{|l|}{ Ventilasi } \\
\hline \multicolumn{7}{|l|}{ Dapur : } \\
\hline TMS & 31 & 73,8 & 11 & 26,2 & 42 & 0,038 \\
\hline MS & 72 & 54,1 & 61 & 45,9 & 133 & \\
\hline Jumlah & 103 & 58,9 & 72 & 41,1 & 175 & \\
\hline \multicolumn{7}{|l|}{ Bahan Bakar } \\
\hline : & & & & & & \\
\hline TMS & 45 & 61,6 & 28 & 38,4 & 73 & 0,633 \\
\hline MS & 58 & 56,9 & 44 & 43,1 & 102 & \\
\hline Jumlah & 103 & 58,9 & 72 & 41,1 & 175 & \\
\hline Keteranga & & & & & & \\
\hline TMS : Tid & $\mathrm{Me}$ & nul & 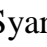 & & & \\
\hline : Me & nu & Sya & & & & \\
\hline
\end{tabular}

Tabel 2. Analisis Multivariat

\begin{tabular}{lccccc}
\hline \multicolumn{1}{c}{ Variabel } & B & Wald & df & Sig & $\begin{array}{c}\text { Exp } \\
(\mathbf{B})\end{array}$ \\
\hline $\begin{array}{l}\text { Ventilasi } \\
\text { dapur }\end{array}$ & 0,219 & 0,143 & 1 & & \\
Jenis lantai & 0,532 & 0,558 & 1 & 0,706 & 1,245 \\
Ventilasi & 1,161 & 3,635 & 1 & 0,057 & 1,703 \\
\hline
\end{tabular}

\section{Hubungan Ventilasi Rumah dengan Kejadian ISPA pada Bayi}

Hasil uji statistik diperoleh nilai $\mathrm{p}=0,04$ maka dapat disimpulkan ada hubungan signifikan antara ventilasi rumah dengan kejadian ISPA.

Penelitian ini sejalan dengan penelitian yang dilakukan oleh Nurhidayati (2009) yang mengatakan bahwa terdapat hubungan yang signifikan antara ventilasi dengan kejadian ISPA, dengan nilai $\mathrm{p}=0,000$ dan OR 5,125 (2,261-11,619).

Bakteri-bakteri patogen penyebab ISPA dapat di bebaskan dari udara ruangan mengalir keluar melalui ventilasi yang memenuhi syarat. Kelembapan udara didalam ruangan naik menyebabkan bakteri dapat berkembang dengan baik, namun pada ventilasi yang memenuhi syarat hal ini tidak akan terjadi karena ventilasi yang baik menjaga kelembapan diruangan menjadi optimum.

\section{Hubungan Jenis lantai Rumah dengan Kejadian ISPA pada Bayi}

Hasil uji statistik diperoleh nilai $\mathrm{p}=$ 0,035 maka dapat disimpulkan ada hubungan signifikan antara jenis lantai rumah dengan kejadian ISPA.

Penelitian ini serupa dengan penelitian Reyes (1999) di Meksiko bahwa ada hubungan yang signifikan antara lantai dengan kejadian ISPA dengan nilai $\mathrm{p}=$ 0,040, dengan OR 2,37(1,04-5,42).

Kelembapan ruangan dapat meningkat disebabkan oleh lantai yang tidak rapat air seperti lantai tanah, atau plester. Hal ini dapat menyebabkan udara diruangan naik akibat penguapan cairan sehingga bakteri mudah berkembang biak dan menyebabkan penyakit seperti penyakit ISPA. Selain lingkungan yang kotor seperti lantai yang berdebu juga menyebabkan kejadian ISPA pada bayi.

\section{Hubungan Kepadatan Hunian dengan Kejadian ISPA pada Bayi}

Hasil uji statistik diperoleh nilai $\mathrm{p}=$ 0,039 maka dapat disimpulkan ada 
hubungan signifikan antara kepadatan hunian dengan kejadian ISPA.

Penelitian ini sejalan dengan penelitian Astrid (2014) dalam penelitiannya mengatakan bahwa ada hubungan yang signifikan antara kepadatan hunian dengan kejadian ISPA dengan nilai $\mathrm{p}=0,011$ Begitu juga dengan penelitian Darmage (1996) dimana terdapat hubungan antara jumlah penghuni rumah dengan kejadian ISPA dengan nilai $\mathrm{p}=0,001$.

Semakin banyak penghuni rumah berkumpul dalam suatu ruangan kemungkinan mendapatkan risiko untuk terjadinya penularan penyakit akan lebih mudah, khususnya bayi yang relatif rentan terhadap penularan penyakit. Semakin banyak penghuni rumah menyebabkan aliran udara tidak terlalu besar sehingga mikroba berada di udara dalam waktu yang lama sehingga kemungkinan untuk masuk ketubuh besar.

Hubungan Ventilasi Dapur dengan Kejadian ISPA pada Bayi

Hasil uji statistik diperoleh nilai $\mathrm{p}=$ 0,038 maka dapat disimpulkan ada hubungan signifikan antara ventilasi dapur dengan kejadian ISPA.

Penelitian ini sejalan dengan penelianti Dharmage (1996) yang mengatakan bahwa ada hubungan yang dignifikan antara kepemilikan lubang asap dapur dengan kejadian ISPA pada anak, dengan nilai $\mathrm{p}=$ 0,049 .

Asap dapur dapat menyebabkan gangguan pernapasan . Pembakaran yang terjadi di dapur rumah menjadi sumber pengotoran atau pencemaran udara. Pengaruh kesehatan akan tampak apabila kadar zat pengotor meningkat sehingga timbul penyakit. Pengaruh zat kimia ini pertama-tama akan timbul pada sistem pernapasan dan kulit serta selaput lendir, selanjutnya apabila zat pencemar masuk ke peredaran darah maka efek sistemik tidak dapat dihindari.Lubang asap yang tidak memenuhi persyaratan menyebabkan gangguan terhadap pernapasan.

Hubungan Bahan Bakar Masak dengan Kejadian ISPA pada Bayi

Hasil uji statistik diperoleh nilai $\mathrm{p}=$ 0,633 maka dapat disimpulkan tidak ada hubungan signifikan antara bahan bakar masak dengan kejadian ISPA.

Penelitian ini sejalan dengan penelitian yang Astrid (2014) yang mengatakan bahwa tidak ada hubungan yang signifikan antara bahan bakar masak dengan kejadian ISPA dengan nilai $\mathrm{p}=0,678$

Penelitian ini didapat bahwa tidak ada hubungan antara bahan bakar masak dengan kejadian ISPA pada bayi. Berdasarkan hasil pengamatan langsung di lapangan didapatkan bahwa ibu memasak dengan menggunakan bahan bakar masak yang tidak memenuhi syarat seperti kayu atau minyak tanah dengan kondisi dapur memenuhi syarat yaitu sebesar $64,4 \%$, dimana dapur memiliki ventilasi $>10 \%$ luas lantai dan terpisah dari rumah induk, sehingga asap yang dihasilkan tidak memasuki rumah. Selain itu pada saat ibu memasak anak di tempatkan jauh dari dapur.

\section{SIMPULAN}

Keadaan ventilasi merupakan faktor paling dominan mempengaruhi ISPA bayi.

\section{UCAPAN TERIMAKASIH}

Penulis mengucapkan terima kasih kepada Kepala Dinas Kesehatan Kabupaten Pasaman beserta Pimpinan Puskesmas di Wilayah Kerja Kabupaten Pasaman, serta petugas kesehatan setempat yang telah memberikan kesempatan dan membantu untuk melakukan penelitian

\section{REFERENSI}

Astrid. (2013). Exposure to Envvironmental Factors with Acute Respiratory Infection (ARI) Among Children 
Under Five Years at Hamlet 1 of Ciampea Village. Globallimunators

Bates, Michael. (2013). Acute Lower Respiratory Infection in Childhood and Household Fuel Use in Bakhtapur, Nepal. Enviromental Health Perspectiv

Badan Pusat Statistik. Survei Demografi dan Kesehatan Indonesia. Jakarta. 2012

Chen, Yinxi (2014). Risk Factors for Acute Respiratory Infection in the Australian Community

Cogswell, J. J., Halliday, D. F., \& Alexander, J. R. (1982). Respiratory Infections in the Year of Life in Children at Risk of Developing Atopy. British Medical Journal

Dharmage, S. C., Rajapaksa, L. C., \& Fernando, D. N. (1996). Risk Factor of Acute Lower Respitratory Tract Infection in Children Under Five Years Of Age. Southes Asian J Trop Med Public Health

Fakhriadi. (2015). Factor Associated with Infection Disease Acute Respiratory Infection to Children in the Area Work of Bukit Hindu Publick Health Center.Building Health Community

Farhan. (2013). Gambaran Faktor Risiko Penderita ISPA Pada Balita di Kelurahan Heledulaa Utara Kecamatan Kota Timur Kota Gorontalo

Hall, \& Breese, C. (2015). Nosocomial Respiratory Syncytial Virus Infection : The Cold War Has Not Ended. Oxford Journal

Morley, C. J., Thornton, A. J., \& Fowler, A. M. (1990, July 5). Respiratory Rate and Severity of Illness in Babies Under 6 Months Old. Archives of Disease in Childhood

Nurhidayati, Istianna. Lingkungan Fisik Rumah dengan Kejadian Penyakit ISPA pada Balita di Wilayah Kerja
Puskesmas Karangnongko

Kabupaten Klaten; 2009

Reyes, Hortensia. (1997). Infant Mortality Due To Acute Respiratory Infection : The Influence off Primary Care Processes. Oxford University Press

Rudianto. (2013). Faktor-faktor yang berhubungan dengan Gejala Infeksi Saluran Pernapasan Acute pada Balita di Posyandu Desa Tamansari Kecamatan Pangkalan Karawang

Soolani (2013). Hubungan Antara Faktor Lingkungan Fisik Rumah dengan Kejadian Infeksi Saluran Pernapasan Akut Pada Balita di Kelurahan Malalayang Kota Menado

Wardhani, Eka. (2010). Hubungan Faktor Lingkungan, Sosial Ekonomi, Pengetahuan Ibu dengan Kejadian ISPA pada Balita di Kelurahan Cicadas Kota Bandung

Wempie, Y. Penyakit Infeksi Saluran Pernapasan Akut. 2013. (Diunduh 04 Maret 2015). Tersedia dari penkeskami. blogspot.com/penyakitinfeksi-pernapasan.html 